\title{
Electrocardiogram Artifacts Caused by Deep Brain Stimulation
}

\author{
Constantine Constantoyannis, Brett Heilbron, Christopher R. Honey
}

\begin{abstract}
Background: Deep brain stimulation (DBS) is increasingly used to treat a variety of neurological conditions (e.g. movement disorders and chronic pain). This prospective study was designed to detect electrocardiogram (ECG) artifacts induced by deep brain stimulation and to investigate which factors (patient disease, electrode position within the brain or type of stimulation) produced these artifacts. Methods: Twelve patients (four women, eight men) with deep brain stimulators were enrolled in the study. Patients were selected to represent the common indications for DBS (Parkinson's disease, tremor, dystonia), the common electrode locations (pallidum, thalamus, subthalamic nucleus) and the two types of stimulation (monopolar, bipolar). Patients had one ECG with the DBS turned 'on' and another with the DBS turned 'off'. The ECGs were then randomized and read by a cardiologist blinded to the status of the patient and DBS and artifacts were noted to be either present or absent. Results: The six patients using monopolar stimulation all had artifacts on their electrocardiograms. These artifacts were severe enough to interfere with ECG interpretation. There were no artifacts detected in the six patients using bipolar stimulation. Electrode location and patient disease appeared to have no effect on ECG artifact. Conclusions: Deep brain stimulation can cause ECG artifacts when monopolar settings are used. These artifacts are not present with bipolar settings or when the DBS is turned 'off'. Knowledge of these potential ECG artifacts and how to avoid them is essential to facilitate accurate ECG interpretation.
\end{abstract}

\begin{abstract}
RÉSUMÉ: Artefacts électrocartiographiques causés par la stimulation cérébrale profonde. Introduction: La stimulation cérébrale profonde (SCP) est de plus en plus utilisée pour traiter différents problèmes neurologiques (i.e. les désordres du mouvement et la douleur chronique). Cette étude prospective a été conçue pour détecter des artefacts électrocardiographiques induits par la stimulation cérébrale profonde et pour étudier quels facteurs (maladie, position des électrodes dans le cerveau ou type de stimulation) produisent ces artefacts. Méthodes: Douze patients, quatre femmes et huit hommes, ayant un stimulateur cérébral profond, ont été recrutés pour participer à cette étude. Les patients étaient choisis parce qu'ils présentaient les indications usuelles de la SCP (maladie de Parkinson, tremblement, dystonie), des localisations fréquentes des électrodes (pallidum, thalamus, corps de Luys) et les deux types de stimulation (monopolaire, bipolaire). Les patients ont subi deux ÉCG, un sous SCPet l'autre sans SCP. Les ÉCG étaient alors répartis au hasard et lus par un cardiologue qui ignorait le statut du patient et de la SCP. Les artefacts étaient décrits comme présents ou absents. Résultats: Les six patients sous stimulation monopolaire avaient tous des artefacts à l'ÉCG. Ces artefacts étaient assez sévères pour interférer avec l'interprétation de l'ÉCG. Aucun artefact n'a été détecté chez les six patients sous stimulation bipolaire. La localisation des électrodes et la maladie du patient ne semblaient pas influencer la présence des artefacts à l'ÉCG. Conclusions: La stimulation cérébrale profonde peut causer des artefacts électrocardiographiques quand un dispositif monopolaire est utilisé. Ces artéfacts sont absents lorsque le dispositif est bipolaire ou quand la SCP n'est pas active. La connaissance de ces artefacts électrocardiographiques et de la façon de les éviter est essentielle à une interprétation juste de l’ÉCG.
\end{abstract}

Can. J. Neurol. Sci. 2004; 31: 343-346

Deep brain stimulation (DBS) has been demonstrated to be very effective and is increasingly used worldwide for the treatment of Parkinson's disease, dystonia, tremor and intractable pain. ${ }^{1-6}$ The components used for DBS include an electrode placed stereotactically into the appropriate brain target, an implantable neural stimulator (INS) typically placed subcutaneously below the clavicle and a connecting wire which joins them. The INS functions as a pacemaker and delivers high frequency electrical pulses to the brain target. Our typical stimulation parameters are $130-185 \mathrm{~Hz}, 90-120 \mu$ s pulse width, and 1-4 V. The effects depend on the brain target selected (e.g. reducing bradykinesia in Parkinson's disease, blocking the tremor of multiple sclerosis or alleviating chronic pain).

From the Divisions of Neurosurgery $(\mathrm{CC}, \mathrm{CRH})$ and Cardiology $(\mathrm{BH})$, University of British Columbia, Vancouver, Canada.

Received September 24, 2003. ACCePted infinAlform DeCEMBer 19, 2003. Reprint requests to: Christopher R. Honey, Division of Neurosurgery, University of British Columbia, Suite 325, 700 West 10th Avenue, Vancouver, BC Canada V5Z 4E5 
During the management of these patients, the authors have noticed that certain settings of the DBS can produce artifacts on the electrocardiogram (ECG). This study was designed to determine which settings produced these artifacts and to highlight this potential problem for physicians who may not be familiar with this new but increasingly more common technology.

\section{Methods}

Twelve patients with movement disorders who underwent DBS electrode implantation were enrolled in the study. All subjects were operated on at the Surgical Centre for Movement Disorders at the University of British Columbia. The brain electrodes (models 3387-40 or 3389-40 Medtronic Inc., Minneapolis, MN) were placed under local anesthesia using CT or MRI stereotactic guidance. The INS (models 7424, 7426 or 7428; Medtronic) was placed in a subcutaneous pocket below the clavicle under general anesthesia, and was connected by an extension to the DBS electrode. The stimulation was started six weeks after the implantation.

Each electrode is insulated except at its tip which has four $1.5 \mathrm{~mm}$ long platinum-iridium contacts spaced $1.5 \mathrm{~mm}$ or $0.5 \mathrm{~mm}$ apart. Using a telemetry wand in the office, the stimulation parameters were adjusted to produce the best clinical effect (and avoid side effects). Pulse frequency, width, voltage and which contacts are used can all be controlled by the clinician. The patient can also control whether the stimulation is turned 'on'or 'off' and in some cases can vary the parameters within set limits.

'Bipolar' stimulation uses one contact of the electrode in the brain as anode and another contact as the cathode. This type of stimulation produces a very focused current field with the maximal effect near the cathode. 'Monopolar' stimulation uses one of the contacts as the cathode and the INS casing (in the chest) as the anode. This provides a radial current diffusion, covering a spherical space around the stimulating electrode.

In this series, we examined the ECG of twelve patients. Six had monopolar stimulation and six had bipolar stimulation. Two ECGs were taken for each patient: the first with the DBS turned 'on' and the second with DBS turned 'off'. Each ECG was randomized and then reviewed by a cardiologist blinded to the DBS status, and the artifacts documented.

In order to compare our results with other centers, a Medline search using the word "electrocardiogram artifacts" was performed. Additional papers were added following a review of the references.

\section{RESUlts}

Twelve patients (four women, eight men) with movement disorders were included in the study with a mean age of 51.5 years (range 23 to 82 years). There were seven patients with Parkinson's disease, three patients with tremor and two patients with dystonia. These are the three most common indications for DBS. The DBS electrodes were implanted in the subthalamic nucleus in three patients, in the pallidum in six patients and in thalamic ventral intermediate nucleus in three patients (Table). These are the three most common targets for DBS.

All six patients using monopolar stimulation had artifacts on their ECGs (Figure 1A and 2A). These artifacts stopped as soon
Table: ECG artifacts in the patients with deep brain stimulators.

\begin{tabular}{|c|c|c|c|c|c|}
\hline Patient & It Disease & $\begin{array}{l}\text { Electrode } \\
\text { Position }\end{array}$ & $\begin{array}{l}\text { INS } \\
\text { Position }\end{array}$ & $\begin{array}{c}\text { Stimulation } \\
\text { (active contacts) }\end{array}$ & Artifact \\
\hline 1 & PD & R-GPi & $\mathrm{R}$ & $\begin{array}{l}\text { Monopolar } \\
3.0 \mathrm{~V} / 120 \mu \mathrm{s} / 185 \mathrm{~Hz}\end{array}$ & Yes \\
\hline 2 & PD & R-GPi & $\mathrm{R} \mu$ & $\begin{array}{c}\text { Bipolar } \\
2+) 3.2 \mathrm{~V} / 120 \mu \mathrm{s} / 185 \mathrm{~Hz}\end{array}$ & No \\
\hline 3 & PD & L-GPi & (1-, & $\begin{array}{l}\text { Monopolar } \\
\text { 2-) } 2.2 \mathrm{~V} / 120 \mu \mathrm{s} / 185 \mathrm{~Hz}\end{array}$ & Yes \\
\hline 4 & PD & L-GPi & $(0-$, & $\begin{array}{c}\text { Bipolar } \\
2+) 2.9 \mathrm{~V} / 120 \mu \mathrm{s} / 185 \mathrm{~Hz}\end{array}$ & No \\
\hline 5 & PD & $\mathrm{R}, \mathrm{L}-\mathrm{STN}$ & $\begin{array}{l}\mathrm{R}(1 \\
\mathrm{L}(4\end{array}$ & $\begin{array}{l}\text { Monopolar } \\
-, 2-) 1.4 \mathrm{~V} / 90 \mu \mathrm{s} / 135 \mathrm{~Hz} \\
--, 5-) 1.4 \mathrm{~V} / 90 \mu \mathrm{s} / 135 \mathrm{~Hz}\end{array}$ & Yes \\
\hline 6 & PD & R,L-STN & $\begin{array}{l}\mathrm{L} \\
\quad \mathrm{R}(0 \\
\mathrm{L}(4\end{array}$ & $\begin{aligned} & \text { Bipolar } \\
+, 1-) & 4.0 \mathrm{~V} / 90 \mu \mathrm{s} / 135 \mathrm{~Hz} \\
+, 5-) & 3.3 \mathrm{~V} / 90 \mu \mathrm{s} / 135 \mathrm{~Hz}\end{aligned}$ & No \\
\hline 7 & PD & R,L-STN & $\begin{array}{l}\mathrm{R} \\
\mathrm{L}\end{array}$ & $\begin{array}{l}\text { Monopolar } \\
\text { (1-) } 0.9 \mathrm{~V} / 90 \mu \mathrm{s} / 135 \mathrm{~Hz} \\
\text { (4-) } 1.2 \mathrm{~V} / 90 \mu \mathrm{s} / 135 \mathrm{~Hz}\end{array}$ & Yes \\
\hline 8 & ET & R,L-Vim & $\begin{array}{l}\mathrm{L}, \mathrm{R} \\
\begin{array}{r}\mathrm{R}(0- \\
\mathrm{L}(4-\end{array}\end{array}$ & $\begin{array}{l}\text { Bipolar } \\
\text {,1+) } 2.2 \mathrm{~V} / 120 \mu \mathrm{s} / 185 \mathrm{~Hz} \\
5+5) 2.8 \mathrm{~V} / 120 \mu \mathrm{s} / 185 \mathrm{~Hz}\end{array}$ & No \\
\hline 9 & MS tremor & R-Vim & $(0-$, & $\begin{array}{l}\text { Monopolar } \\
1-) 2.3 \mathrm{~V} / 120 \mu \mathrm{s} / 185 \mathrm{~Hz}\end{array}$ & Yes \\
\hline 10 & MS tremor & L-Vim & (0- & $\begin{array}{c}\text { Bipolar } \\
\text {,3+) } 4.0 \mathrm{~V} / 90 \mu \mathrm{s} / 185 \mathrm{~Hz}\end{array}$ & No \\
\hline 11 & Dystonia & L-GPi & $(0-$ & $\begin{array}{c}\text { Bipolar } \\
\text { 2+) } 3.0 \mathrm{~V} / 90 \mu \mathrm{s} / 135 \mathrm{~Hz}\end{array}$ & No \\
\hline 12 & Dystonia & $\mathrm{R}, \mathrm{L}-\mathrm{GPi}$ & $\begin{array}{l}\mathrm{R}( \\
\mathrm{L}(\end{array}$ & $\begin{aligned} & \text { Monopolar } \\
\text { (2-) } & 3.3 \mathrm{~V} / 90 \mu \mathrm{s} / 135 \mathrm{~Hz} \\
\text { (5-) } & 3.1 \mathrm{~V} / 90 \mu \mathrm{s} / 135 \mathrm{~Hz}\end{aligned}$ & Yes \\
\hline
\end{tabular}

PD: Parkinson's disease, MS: multiple sclerosis, STN: subthalamic nucleus, Vim: ventral intermediate nucleus of thalamus, R: right, L: left, INS: implantable neural stimulator, ET: essential tremor, GPi: Globus pallidus

as the DBS was turned off (Figure $1 \mathrm{~B}$ and $2 \mathrm{~B}$ ). None of the patients using bipolar stimulation had ECG artifacts (Figure 3A with the stimulation 'on' and 3B with the stimulation 'off').

\section{Discussion}

The ECG records electrical potentials produced by the heart but it can also detect electrical activity generated by skeletal muscles, pacemakers and transcutaneous electrical nerve stimulators. $^{7-9}$ Artifacts on the ECG produced by deep brain stimulation and spinal cord stimulation have been reported recently. ${ }^{10,11}$ In the case of DBS, the electrical interference appears to be only evident on the ECG when the stimulator is operating in the monopolar mode. The electrical current is traveling between the contact in the brain (cathode) and the generator below the clavicle (anode) and is of sufficient magnitude to be recorded by the ECG machine. In bipolar mode, 


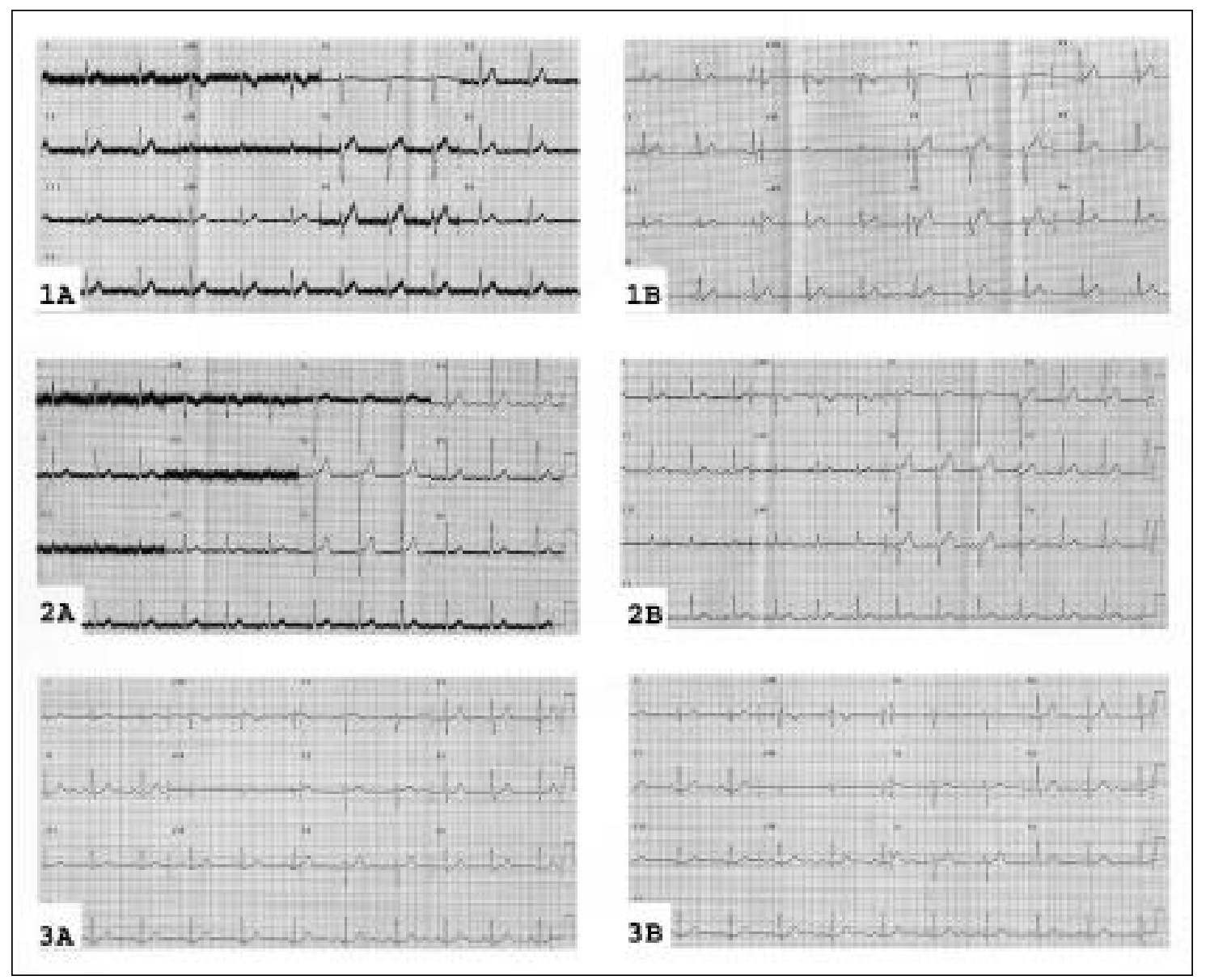

Figure: Twelve lead electrocardiograms done on Patient 1 (see Table) with DBS turned 'on'(1A) and 'off' (1B), Patient 9 with DBS 'on'(2A) and 'off' (2B), and Patient 2 with DBS turned 'on'(3A) and 'off' $(3 B)$.

the current travels between two contacts of the electrode in the brain, and is of insufficient magnitude to be recorded by the ECG machine.

The use of DBS is rapidly increasing because it can alleviate certain movement disorders or pain with a resultant improvement in the patient's quality of life. ${ }^{12}$ Patients requiring DBS are often elderly and may thus have concurrent cardiac disease.

In this series, all patients using monopolar stimulation had artifacts in their electrocardiograms. There is a tendency for neurosurgeons and neurologists to use monopolar stimulation in patients with dystonia and in patients with subthalamic nucleus stimulators for Parkinson's disease. ${ }^{13}$ These artifacts were immediately reversible once the DBS was stopped.

Turning the DBS off for the duration of the ECG will usually not have adverse effects (some patients turn the DBS off at night while sleeping to save battery power when they are not troubled by their symptoms). Unfortunately, some patients can have rapid deterioration if their DBS is turned off (e.g. severe bradykinesia in Parkinson's disease patients implanted in the subthalamic nucleus). Occasionally an ECG diagnosis is required in someone whose DBS can not just be turned off. Two options are available: an increase of their medications can usually support them while the DBS is off or switching the stimulation to a bipolar setting with appropriate selection of new stimulation parameters (i.e. active contacts, voltage, pulse width and frequency). If clinicians are in doubt, they will need to consult the specialist who programs the patient's DBS.

We conclude that deep brain stimulators using monopolar stimulation will produce ECG artifacts. These artifacts are not present when the DBS is turned off or when bipolar stimulation is used. Awareness of these artifacts and how to prevent them will facilitate accurate ECG interpretation.

\section{REFERENCES}

1. Benabid AL, Pollak P, Gervason C, et al. Long-term suppression of tremor by chronic stimulation of the ventral intermediate thalamic nucleus. Lancet 1991; 337: 403-406.

2. Limousin P, Krack P, Pollak P, et al. Electrical stimulation of the subthalamic nucleus in advanced Parkinson's disease. N Engl J Med 1998; 339: 1105-1111.

3. Kumar R, Dagher A, Hutchinson WD, et al. Globus pallidus deep brain stimulation for generalized dystonia: clinical and PET investigation. Neurology 1999; 53: 871-874.

4. Bebabid A, Benazzouz A, Hoffmann D, et al. Long-term electrical 
inhibition of deep brain targets in movement disorders. Mov Disord 1998; 13(Suppl 3): 119-125.

5. Bendok B, Levy R. Brain stimulation for persistent pain management. In: Gildenberg P, Tasker P, (Eds). Textbook of Stereotactic and Functional Neurosurgery. New York: McGrawHill Inc., 1998: 1539-1546.

6. Limousin P, Speelman D, Gielen F, et al. Multicentre European study of thalamic stimulation in parkinsonian and essential tremor. J Neurol Neurosurg Psychiatry 1999; 66: 289-296.

7. Kimberly APS, Soni N, Williams TR. Transcutaneous nerve stimulation and the electrocardiograph. Anesth Intensive Care 1987; 15: 358-359

8. Sliwa JA, Marinko MS. Transcutaneous electrical nerve stimulator induced electrocardiogram artifact. Am J Phys Med Rehab 1996; 75: 307-309.
9. Knight BP, Pelosi F, Michaud GF, et al. Clinical consequences of electrocardiographic artifact mimicking ventricular tachycardia. N Engl J Med 1999; 341: 1270-1274.

10. Martin WA, Camenzind E, Burkhard PR. ECG artifact due to deep brain stimulation. Lancet 2003; 361(9367): 1431.

11. Siddiqui MA, Khan IA. Differential electrocardiographic artifact from implanted spinal cord stimulator. Int J Cardiol 2003, 87: 307-309.

12. Berk C, Carr J, Sinden M, et al. Thalamic deep brain stimulation for the treatment of tremor due to multiple sclerosis: a prospective study of tremor and quality of life. J Neurosurg 2002; 97: 815820.

13. Pollak P, Benabid AL, Krack P, et al. Deep brain stimulation. In: Jancovic J, Tolosa E, (Eds). Parkinson's Disease and Movement Disorders. Baltimore : Williams \& Wilkins, 1998: 1085-1101. 